\title{
Characterization of a cold-active esterase from Serratia sp. and improvement of thermostability by directed evolution
}

\author{
Huang Jiang ${ }^{1,2+}$, Shaowei Zhang ${ }^{1,2+}$, Haofeng Gao $^{1}$ and Nan Hu${ }^{1 *}$
}

\begin{abstract}
Background: In recent years, cold-active esterases have received increased attention due to their attractive properties for some industrial applications such as high catalytic activity at low temperatures.

Results: An esterase-encoding gene (estS, 909 bp) from Serratia sp. was identified, cloned and expressed in Escherichia coli DE3 (BL21). The estS encoded a protein (EstS) of 302 amino acids with a predicted molecular weight of $32.5 \mathrm{kDa}$. It showed the highest activity at $10^{\circ} \mathrm{C}$ and $\mathrm{pH} 8.5$. EstS was cold active and retained $\sim 92 \%$ of its original activity at $0{ }^{\circ} \mathrm{C}$. Thermal inactivation analysis showed that the $T_{1 / 2}$ value of EstS was 50 min at $50{ }^{\circ} \mathrm{C}$ (residual activity $41.23 \%$ ) after $1 \mathrm{~h}$ incubation. EstS is also quite stable in high salt conditions and displayed better catalytic activity in the presence of $4 \mathrm{M} \mathrm{NaCl}$. To improve the thermo-stability of EstS, variants of estS gene were created by error-prone PCR. A mutant 1-D5 (A43V, R116W, D147N) that showed higher thermo-stability than its wild type predecessor was selected. 1-D5 showed enhanced $\mathrm{T}_{1 / 2}$ of $70 \mathrm{~min}$ at $50{ }^{\circ} \mathrm{C}$ and retained $63.29 \%$ of activity after incubation at $50{ }^{\circ} \mathrm{C}$ for $60 \mathrm{~min}$, which were about $22 \%$ higher than the wild type (WT). CD spectrum showed that the secondary structure of WT and 1-D5 are more or less similar, but an increase in $\beta$-sheets was recorded, which enhanced the thermostability of mutant protein.
\end{abstract}

Conclusion: EstS was a novel cold-active and salt-tolerant esterase and half-life of mutant 1-D5 was enhanced by 1.4 times compared with WT. The features of EstS are interesting and can be exploited for commercial applications. The results have also provided useful information about the structure and function of Est protein.

Keywords: Esterase, Cold-active, Salt-tolerant, Serratia sp, Thermo-stability, Error-prone PCR

\section{Background}

Esterases (EC 3.1.1.3, carboxyl ester hydrolases), lipases (EC 3.1.1.1, triacylglycerol hydrolases) and phospholipase, commonly referred to as lipolytic enzymes, principally catalyze the hydrolysis and synthesis of acyl glycerides and other fatty acid esters [1]. Lipolytic enzymes produced from psychrophilic microorganisms in cold environment could be active and stable at low temperatures as compared to mesophilic enzymes. Esterases have gained immense importance in pharmaceutical, polymer, food, flavor, oleochemical, biofuel and detergent industries [2]. The high catalytic activity of these lipolytic enzymes at

\footnotetext{
* Correspondence: hunan@njtech.edu.cn

${ }^{\dagger}$ Equal contributors

'College of Biotechnology and Pharmaceutical Engineering, Nanjing Tech

University, Nanjing 211800, P. R. China

Full list of author information is available at the end of the article
}

low temperatures make these more useful for commercial applications [3]. Recently, many cold-active lipolytic enzymes from psychrophiles and psychrotrophs have been discovered and characterized [4-6]. In esterses, the catalytic triad is commonly formed by Ser, His and Asp residues followed the order Ser-Asp-His and the nucleophilic serine residue is usually embedded in a conserved pentapeptide motif (G-X-S-X-G) [7]. In the past decade, a quick progress achieved in the production of recombinant esterases by directed evolution, mutagenesis, structural analysis, protein engineering [8]. Therefore, attempts have been made to enhance the thermo-stability of lipolytic enzymes by directed evolution $[9,10]$. The directed evolution is generally used to generate desired variants and investigate the relationship of structure-function without any detailed structure information [11, 12]. Directed evolution creates molecular diversity by various methods such 
as error-prone PCR, site-specific saturation mutagenesis and DNA shuffling [13-15]. Recently, an esterase of pig liver origin mutated at F407I was used to resolve the racemic mixture of clopidogrel [16]. Our previous studies also confirmed that a cold active esterase (Est11), produced from Psychrobacter pacificensis, was salt tolerant, highly active at low temperatures, and its biochemical characteristics made it important for commercial applications [17]. Serratia is a genus of Gram-negative, rod-shaped bacteria and is also a well-known source for chitinase production [18]. Only few reports of esterase from Serratia sp. are available in literature.

In this study, a gene encoding a cold-active esterase, termed EstS, was cloned from the marine bacterium Serratia sp. and expressed in E. coli. The recombinant enzyme was purified to homogeneity and characterized. Furthermore, the effect of altered amino acid on the thermo-stability of esterase was studied by 3D structural model of esterase and circular dichroism (CD) analysis.

\section{Results}

\section{Gene cloning and sequence analysis}

The esterase gene, estS, was successfully cloned from Serratia sp. genomic DNA. The gene was 909 bp long and encoded a protein (EstS) of 302 amino acids with a theoretical molecular weight of $32.5 \mathrm{kDa}$. The SignalP 4.1 Server predicted no signal peptide for EstS. BLASTP revealed that the translated protein sequences of EstS showed a high sequence identity to esterase [GenBank: WP_020827011.1] from Serratia liquefaciens ATCC 27592 (identity, $98 \%$ ), esterase [GenBank: WP_044551387.1] from Serratia liquefaciens FK01 (92 \%), and esterase [GenBank: WP_037415500.1] from Serratia grimesii (82\%). A multiple sequence alignment of EstS was performed with thermophilic carboxylesterase Est2 [PDB: 1EVQ_A] from Alicyclobacillus acidocaldarius (identity: 41 \%), esterase PestE [PDB: 2YH2_A] from Pyrobaculum calidifontis (41\%), carboxylesterase Este1 [PDB: 2C7B_A] from a metagenomic library (40\%), esterase Lpest1 [PDB: 4C88_A] from Lactobacillus plantarum (29\%), and all of them were retrieved using BLASTP in the NCBI and PDB database (Fig. 1). The classical catalytic triad consisting of Ser 157, Asp 252 and His 282 was identified and the active site Ser 157 residue was located within the conserved pentapeptide motif (Gly-X-Ser-X-Gly).

\section{Screening of random mutant library}

Screening of random mutant library was based on retention of esterase activity after incubation at high temperature. A clone, designated as 1-D5, which displayed higher thermo-stability than WT enzyme, was selected from over 8000 clones. Sequencing of gene revealed that 1-D5 showed three alterations in amino acid residues (A43V, R116W, D147N).

\section{Expression and purification}

The protein WT and mutant fused with GST tag $(58 \mathrm{kDa})$ were efficiently induced and overexpressed as a soluble, catalytically active form in host strain at $15{ }^{\circ} \mathrm{C}$. The purified WT and mutant $(\sim 32 \mathrm{kDa})$ were detected by SDS-PAGE as a single band, which was consistent with the value predicted from the deduced amino-acid sequence (Fig. 2).

\section{Substrate specificities}

The substrate specificity of WT was determined against various aliphatic acyl-chain $p$-NP esters (C2-C16). EstS showed the maximum hydrolytic activity towards $p$-NP acetate (C2), but no activity toward $p$-NP palmitate (Fig. 3). The results indicated that purified protein was an esterase rather than a lipase due to its preference for short acyl-chain $p$-NP esters.

\section{Biochemical characterization of WT and mutant}

The optimum activity of WT and mutant was measured over a temperature range of $0-80{ }^{\circ} \mathrm{C}$ and a $\mathrm{pH}$ range of 5-10 WT showed the maximum activity around $10{ }^{\circ} \mathrm{C}$ and retained nearly $92 \%$ activity at $0{ }^{\circ} \mathrm{C}$. The properties of higher hydrolytic activity at a low temperature indicated that EstS was a cold-active enzyme. However, no change in optimum temperature of mutant esterase was observed when compared with WT (Fig. 4a). Thermostability analysis showed that $\mathrm{T}_{1 / 2}$ of WT esterase was about $50 \mathrm{~min}$ at $50{ }^{\circ} \mathrm{C}$ with $41.23 \%$ of its original activity after $1 \mathrm{~h}$ incubation. Also, complete loss of WT activity was reported after $20 \mathrm{~min}$ incubation at $55{ }^{\circ} \mathrm{C}$ (Fig. 4b). In contrast, the mutant enzyme showed enhanced $\mathrm{T}_{1 / 2}$ of $70 \mathrm{~min}$ at $50{ }^{\circ} \mathrm{C}$ and retained $63.3 \%$ of its initial activity after incubation at $50{ }^{\circ} \mathrm{C}$ for $60 \mathrm{~min}$, which were about $22 \%$ higher than WT. The $\mathrm{pH}$ activity profile of WT and mutant was examined over the $\mathrm{pH}$ range of 5-10 under optimized assay conditions (Fig. 4c). The optimal $\mathrm{pH}$ of WT and mutant esterase was found to be 8.5. WT was stable over a wide $\mathrm{pH}$ range of 5.5-9.5, but almost inactive at $\mathrm{pH} 5$ when compared with 1-D5 (Fig. 4d).

The effects of various additives on the EstS activity were examined. EstS was slightly activated by $1 \mathrm{mM} \mathrm{Mg}^{2+}$ (remaining activity, $121 \%$ ), 1 and $5 \mathrm{mM}$ $\mathrm{Mn}^{2+}(120 \%, 114 \%$ respectively), whereas it was fairly inhibited by $1,5 \mathrm{mM} \mathrm{Zn}^{2+}(83 \%, 71 \%)$ and $\mathrm{Cu}^{2+}(87 \%$, $52 \%$ ) and $5 \mathrm{mM}$ PMSF (89 \%). The mutant 1-D5 showed a similar behavior in the presence of metal ions and relative activity was slightly increased by $\mathrm{Mn}^{2+}$ and strongly decreased by the presence of $\mathrm{Zn}^{2+}$ and PMSF. However, the activity of EstS was not affected by the presence of EDTA, $\mathrm{Ca}^{2+}, \mathrm{Ba}^{2+}$ and $\mathrm{Sr}^{2+}$ (Table 1). The activity of EstS was also strongly reduced by higher concentrations of isopropanol, methanol and ethylene glycol 


\begin{tabular}{|c|c|c|}
\hline Ests & $\ldots \ldots \ldots$ MPLDFQIARELAEAA $\ldots$ QAPAFASISEMREVAHAGLIALQGEAEASGGVRDGWVTADDG & 57 \\
\hline Est2 & . . . . . MPLDFVIQQVLDQLN. . RMPAPDYKHLSAQQFRSQQSLE PFVKREPVAEVREFDXDLPG & 57 \\
\hline Este1 & 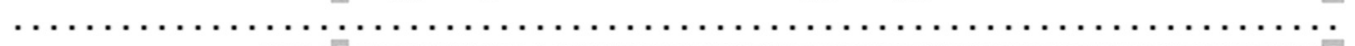 & 0 \\
\hline Peste & $\ldots \ldots \ldots \ldots M P L S P I L R Q I L Q Q L A A Q L Q F R P D M D V K T V R E Q F E K S S I I L V K M A N E P I H R V E D I T I P G R G$ & 60 \\
\hline Ipest1 & GGSHHHHHHGENLYFQGMET INSIQTTVNGVVKIVKPFNNDIAGEQFDPHVLQTLTAFRQPAILENDLAZLRSG & 74 \\
\hline Ests & $\ldots \ldots \ldots$ RAIAIRAYTPGGATPGEPLPAMIYZHGGGWCIGSLALYDRPCQALANAT & 106 \\
\hline Est2 & . . . . . . . RTLKVRXYRPEGVEPP . YYPALVYYHGGGWVVGDLETHDPVCRVLAKDG & 104 \\
\hline Este1 & $\ldots \ldots \ldots \ldots \ldots$. $\ldots \ldots$ IPAVIYYHGGGFVAGSIETHDHICRRLSRLS & 33 \\
\hline PestE & . LPAVVYYHGGGFVIGSVETHDHVCRRLANLS & 106 \\
\hline Lpest1 & SLTPAIADPVGDAVTVQSRNITALNRTVSVEWLTPQNVIN . . HTVLVYHHGGAFYGGVPGNNTVLLKLVAAKS & 145 \\
\hline Ests & GRVIISVDYRLAPEYPYFRPIBDVYCALCGVVERADEWGVDVARMAVGDSAG GLAAAVAILARDRKGPQIEH & 180 \\
\hline Est2 & RAVVFSVDYRLAPEHKFEAAVEDAYDALQWIAERAADFHLDFARIPVGGDSAGGNLAAVTSILAKERGGPALAF & 178 \\
\hline Este1 & IVSVDYRLAPEYKFETAVEDAYAALKWVADRADELGVDPDRIZWZGDSAGENLAAVVSILDRNSGEKLVKK & 107 \\
\hline Peste & JVVSVDYRLAPEHKAEAAVEDAYDAAKWVADNYDKLGVDNGKIZVZGDSAGSNLAAVTA IMARDRGESFVKY & 180 \\
\hline Lpest1 & PAFAGILDGLAIFQYLEQRDAET . . . MITUZGDSAGHVIMAATNLNQQIGSNRINQ & 214 \\
\hline Ests & EVMAFCWNTYYLGEADKPQDPYAEELHAPMIQR & 240 \\
\hline Est2 & CIIIYFSTGYDPAHPRASIEEN.A.........EGYIITGGXXLWERDQYLNSLEELTHPWFSFVLYPDISG & 240 \\
\hline Este1 & dVIIYFVVNXTGVPTASLVEFGVA.........ETTSIPIELXVWEGRQYLRRPEEAYDFKASE. LLADIGG & 169 \\
\hline PestE & CVIIYEAVNLTGSPTVSRVEYSGP......... EYVIITADLMANEGRQYFSKPQDALSPYASE. IFADISN & 242 \\
\hline Lpest1 & CIIIYFVTAPNADHAGPLWDLAAF PIIDSQRAILTNYHDIGRQLDSIMTDYYVVENF DSHSFLISELHQENFTM & 288 \\
\hline Ests & IPAATILSCEYDELFDEAEIYAKRIQEAGVAVRCERLPGMVRACIMMLGLTPAARVLFDKVG $\ldots \ldots \ldots$ & 302 \\
\hline Est2 & IPFAYIATAQYDELFDVGKIYZEAINKAGVKVEIENFEDIIHGFAQFYSLSPGATKALVRIAERLRDALA. & 310 \\
\hline Este1 & IPEALVVTAEYDFIRDEGEIYAYKXKASGSRAVAVREAGXVFGFVSFYPFVDAGREALDLAAASIRSGLQP & 240 \\
\hline PestE & IPFALVITAEYDFIRDEGEIYAHLIKTRGVRAVAVRYNGVIHGFVNFYPILEEGREAVSQIAASIKS.MAV & 312 \\
\hline Lpest1 & 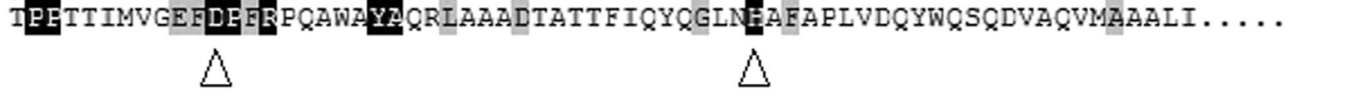 & 354 \\
\hline \multicolumn{3}{|c|}{$\begin{array}{l}\text { Fig. } 1 \text { Multiple alignments of EstS and other four esterases. The four esterases are Est2 [PDB: 1EVQ_A] from Alicyclobacillus Acidocaldarius, PestE } \\
\text { [PDB: } 2 \text { YH2_A] from Pyrobaculum calidifontis, Este1 [PDB: 2C7B_A] from a metagenomic library and Lpest1 [PDB: 4C88_A] from Lactobacillus } \\
\text { Plantarum. The identical and conserved residues are shaded. The conserved G-X-S-X-G motif and the catalytic triad (Ser, Asp, and His) were } \\
\text { indicated by red box and black triangle, respectively }\end{array}$} \\
\hline
\end{tabular}

(20, $30 \%)$ and was almost completely inhibited by Nbutyl alcohol and acetonitrile. Our data also showed that ethanol (10-30\%) increased the activity of the enzyme WT by more than $10 \%$ (Table 2). However, the mutant 1-D5 displayed highest activity in the presence of ethylene glycol $(20 \% \mathrm{v} / \mathrm{v})$ and a slight decrease in the relative activity was observed in the presence of DMSO and short chain alcohols. Non-ionic detergents such as Triton X-100, Tween 20, Tween 80 and CHAPS showed no significant effect on the enzyme activity of EstS WT and mutant while the anionic detergent SDS almost inactivated it (Table 3).

The effect of $\mathrm{NaCl}$ on the EstS enzyme activity and stability was further investigated. EstS was not significantly affected and remained robust even at a concentration of $4 \mathrm{M} \mathrm{NaCl}$ (Fig. 5). EstS was $\mathrm{NaCl}$ - tolerant and retained more than $80 \%$ of its original activity after $24 \mathrm{~h}$ incubation at $4{ }^{\circ} \mathrm{C}$ in the solution of high salinity $(2.4 \mathrm{M}$ $\mathrm{NaCl})$ as depicted in Fig. 5.

\section{Kinetic measurements}

The kinetic parameters of WT and mutant toward $p$-NP acetate were investigated (Table 4). The mutant 1-D5 displayed an $18 \%$ increase in $K_{m}$ and an $8 \%$ increase in $K_{c a t}$, leading to approximately a $10 \%$ decline in catalytic efficiency $K_{\text {cat }} / K_{m}$ (Table 4$)$.

\section{Homology modeling}

The homology models were constructed using swissmodel server with the crystal structure of thermophilic carboxylesterase Est2 [PDB: 1EVQ_A] from Alicyclobacillus acidocaldarius as the template (41\% identity to EstS). Both the predicted models of the WT and mutant enzyme exhibit the typical $\alpha / \beta$ hydrolase fold, which was 


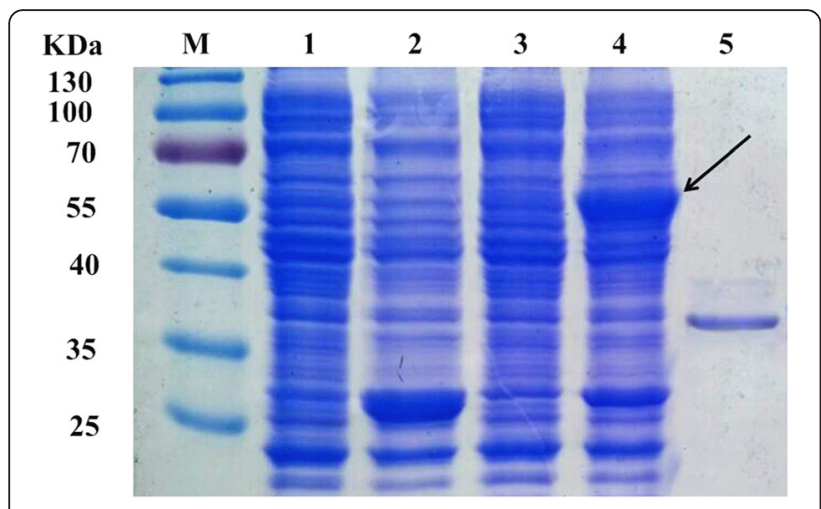

Fig. 2 SDS-PAGE analysis of purified EstS protein. M: Protein molecular weight marker; 1: Uninduced cell lysate of E. coli BL21 (DE3) harboring pGEX-6P-1; 2: IPTG-induced of cell lysate of E. coli BL21 (DE3) harboring pGEX-6P-1; 3: Uninduced cell lysate of E. coli BL21 (DE3) harboring pGEX-6P-estS; 4: IPTG-induced of cell lysate of E. coli BL21 (DE3) harboring pGEX-6P-estS; 5: Purified EstS. The protein GST-EstS is indicated by arrow

characteristic of lipolytic enzymes (Fig. 6). The electrostatic potential of EstS was calculated and described (Fig. 7). The distribution of charges revealed that EstS had high negative charges on the surface.

\section{Circular dichroism and secondary structure prediction}

The program PSIPRED predicted that the residue Arg116 residue was located in a conservative region. A quantitative analysis of the protein secondary structure for WT and mutant was carried out using SELCON3 program. The data showed that the CD spectra of Est WT and 1-D5 was more or less similar and an increase

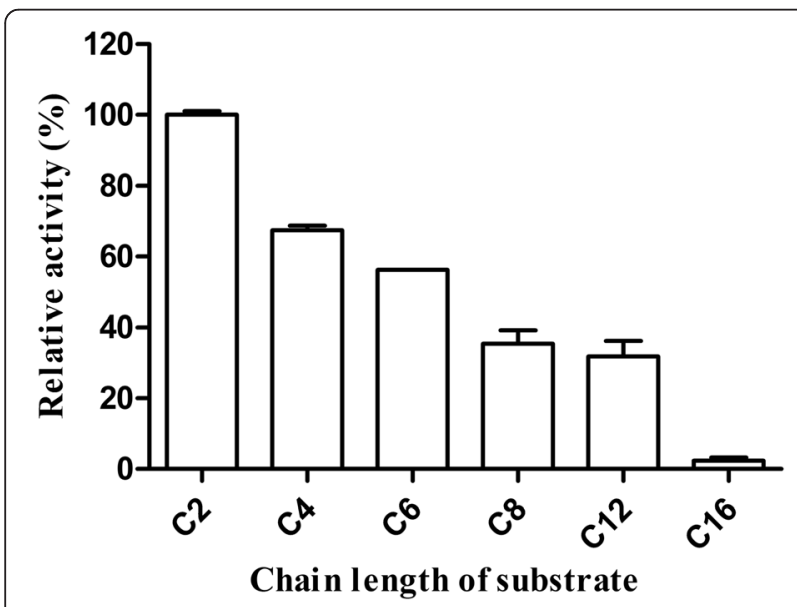

Fig. 3 Substrate specificity of the purified EstS. The esterase activity of EstS was tested with various chain lengths of $p$-NP esters $(C 2, C 4$, $\mathrm{C} 6, \mathrm{C} 8, \mathrm{C} 12$ and $\mathrm{C16}$ ) in $50 \mathrm{mM}$ Tris - $\mathrm{HCl}, \mathrm{pH} 8.5$, at $30^{\circ} \mathrm{C}$. The activity against $p$-NP acetate (C2) was taken as $100 \%$. All measurements were performed in triplicate in the percentage of $\beta$-sheets was reported by $C D$ analysis (Fig. 8).

\section{Discussion}

In this study, we have identified and characterized an esterase (EstS) from a marine bacterium Serratia sp. EstS preferred short-chain $p$-nitrophenyl esters as substrate and unable to hydrolyze long-chain $p$-nitrophenyl esters (C12 and C16). The specificity towards short chain acyl esters indicated that purified protein (EstS) was an esterase. EstS demonstrated the $\mathrm{T}_{1 / 2}$ of approximately $50 \mathrm{~min}$ at $50{ }^{\circ} \mathrm{C}$ and retained $41.23 \%$ activity after $1 \mathrm{~h}$ incubation. In addition, the activity of EstS WT was increased by low concentration $(1 \mathrm{mM})$ of $\mathrm{Mg}^{2+}$ and $\mathrm{Mn}^{2+}$, partly inhibited by $\mathrm{Cu}^{2+}$ and $\mathrm{Zn}^{2+}$, and completely inhibited by the addition of acetonitrile, $n$-butanol and SDS. EstS retain its activity and stability between $\mathrm{pH} 5.5$ and $\mathrm{pH} 9.5$ after $24 \mathrm{~h}$ at $4{ }^{\circ} \mathrm{C}$. Furthermore, we also report the engineering of EstS by directed evolution. A thermo-stable mutant 1-D5 was selected from the random mutant library constructed by error-prone PCR. 1-D5 showed change in three amino acids (A43V, R116W, D147N). No change in optimum temperature and $\mathrm{pH}$ of 1-D5 was observed in comparison to EstS. But the $\mathrm{T}_{1 / 2}$ at $50{ }^{\circ} \mathrm{C}$ of 1-D5 was about $70 \mathrm{~min}$ and it retained $63.3 \%$ of activity at $50{ }^{\circ} \mathrm{C}$ for $1 \mathrm{~h}$, which were about $22 \%$ higher than WT.

Interestingly, EstS displayed a significant adaptation towards low temperature showing the optimal activity at $10{ }^{\circ} \mathrm{C}$ and retained $92 \%$ residual activity at $0{ }^{\circ} \mathrm{C}$ (Fig. 4a). However, EstS was considerably unstable at temperatures above $55{ }^{\circ} \mathrm{C}$. These unique characteristics indicate that EstS is a cold-active enzyme (low optimal temperature, poor thermo-stability). The value of optimal temperature is certainly lower than other reported cold-active esteraseslipases, such as: EstB from Alcanivorax dieselolei $\mathrm{B}-5(\mathrm{~T})$ which showed optimal activity at $20{ }^{\circ} \mathrm{C}$ and retained $95 \%$ of its original activity at $0{ }^{\circ} \mathrm{C}$ [19]; Est10 from $P$. pacificensis displayed optimal activity at $25{ }^{\circ} \mathrm{C}$ and retained $55 \%$ of its original activity at $0{ }^{\circ} \mathrm{C}$ [20]; rEst97 from deep-sea sediment had shown optimal activity at $35{ }^{\circ} \mathrm{C}$ and about $12 \%$ relative activity at $0.5{ }^{\circ} \mathrm{C}$ [21]; lipase hiLip1 from uncultured microorganism with the optimal activity at $35{ }^{\circ} \mathrm{C}$ and $44 \%$ activity at $10{ }^{\circ} \mathrm{C}$ [22]. However, the EstS is slightly more stable at high temperature(s) than all these cold-active lipolytic enzymes, which were rapidly inactivated at $55^{\circ} \mathrm{C}$.

The adaptation of cold-active enzyme to low temperatures can be attributed to the conformational flexibility conferred by some structural features: more Gly residues (especially around the active site); less Pro and Arg residues; more Ser and Met [22-24]. Comparatively, EstS has higher percentage of small amino acids Ala (16.56 \%) and Gly $(8.94 \%)$ than its thermophilic counterpart Est2 

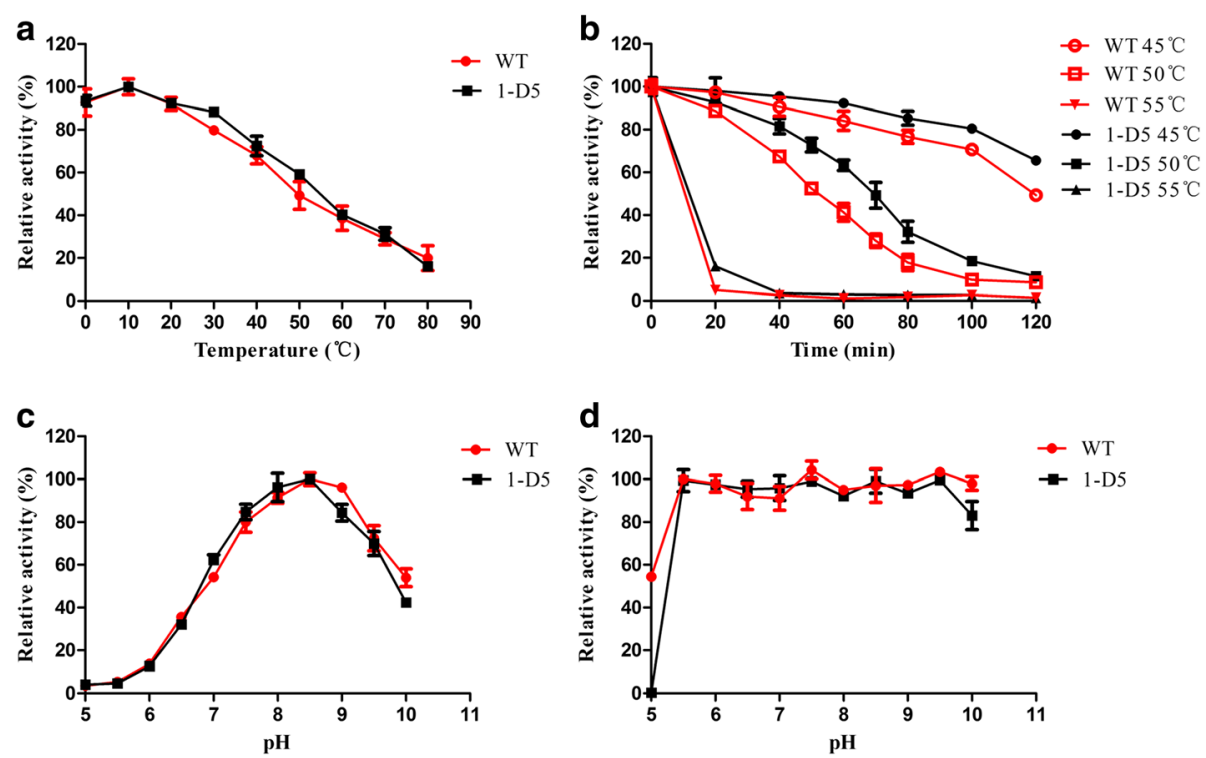

Fig. 4 Effect of temperature and pH on enzyme activity and stability of WT and mutant. a The effect of temperature on enzyme activity. The temperature-activity profile was measured at a temperature range of 0 to $80^{\circ} \mathrm{C}$ in $50 \mathrm{mM}$ Tris- $\mathrm{HCl}$ buffer ( $\left.\mathrm{pH} 8.5\right)$. Activity value obtained at $10{ }^{\circ} \mathrm{C}$ was defined as $100 \%$. b Temperature stability. The WT and mutant enzyme was incubated at 45 (o WT; • 1-D5), 50 ( $\square$ WT; $\bullet 1-D 5)$ and $55^{\circ} \mathrm{C}$

$(\boldsymbol{\nabla}$ WT; $\boldsymbol{\Delta} 1$-D5) for various time intervals and the residual activity was measured. The specific activity without incubation was taken as $100 \%$. c The effect of $\mathrm{pH}$ on enzyme activity. The $\mathrm{pH}$-activity profile was determined in phosphate-citrate buffer (pH 5.0-7.0) and $50 \mathrm{mM}$ Tris- $\mathrm{HCl}$ buffer ( $\mathrm{pH} 7.0-10.0)$ at $10^{\circ} \mathrm{C}$. The activity at $\mathrm{pH} 8.5$ was defined as $100 \%$. $\mathbf{d} \mathrm{pH}$ stability. The activity was determined by pre-incubating enzyme solutions in different pHs buffers at $4{ }^{\circ} \mathrm{C}$ for $24 \mathrm{~h}$ and the residual activity was measured under standard condition. The residual activity after treatment with $\mathrm{pH} 7.0$ buffer was shown as $100 \%$

(Ala $11.94 \%$, Gly $7.10 \%$ ) from Alicyclobacillus acidocaldarius and PestE (Ala $11.94 \%$, Gly $7.35 \%$ ) from Pyrobaculum calidifontis $[25,26]$. Besides, EstS has less Pro $(6.95 \%)$ than Est2 and more Met (2.98 \%) than Est2 $(0.65 \%)$ and PestE $(1.92 \%)$, all this is a factor probably contributing to its adaptation to low temperatures.

Table 1 Effects of various reagents on the activity of EstS and mutant

\begin{tabular}{|c|c|c|c|c|}
\hline \multirow[t]{3}{*}{ Reagents } & \multicolumn{4}{|c|}{ Relative activity (\%) } \\
\hline & \multicolumn{2}{|l|}{ EstS } & \multicolumn{2}{|l|}{ 1-D5 } \\
\hline & $1 \mathrm{mM}$ & $5 \mathrm{mM}$ & $1 \mathrm{mM}$ & $5 \mathrm{mM}$ \\
\hline Control & $9.9 \pm 0.2 \mathrm{U} / \mathrm{ml}$ & $8.6 \pm 0.5 \mathrm{U} / \mathrm{ml}$ & $8.1 \pm 3.2 \mathrm{U} / \mathrm{ml}$ & $8.1 \pm 3.2 \mathrm{U} / \mathrm{ml}$ \\
\hline $\mathrm{Mg}^{2+}$ & $121.8 \pm 1.3$ & $106.5 \pm 5.9$ & $95.0 \pm 4.4$ & $98.3 \pm 1.4$ \\
\hline $\mathrm{Sr}^{2+}$ & $102.0 \pm 1.7$ & $105.3 \pm 2.3$ & $94.2 \pm 4.4$ & $101.1 \pm 1.1$ \\
\hline $\mathrm{Ba}^{2+}$ & $109.7 \pm 5.7$ & $107.6 \pm 7.4$ & $97.2 \pm 3.1$ & $103.2 \pm 5.3$ \\
\hline $\mathrm{Zn}^{2+}$ & $83.1 \pm 3.6$ & $71.6 \pm 4.1$ & $39.9 \pm 6.3$ & $34.2 \pm 4.6$ \\
\hline $\mathrm{Mn}^{2+}$ & $120.7 \pm 4.0$ & $114.9 \pm 4.4$ & $100.1 \pm 7.3$ & $106.2 \pm 0.8$ \\
\hline $\mathrm{Cu}^{2+}$ & $87.6 \pm 4.2$ & $52.1 \pm 4.0$ & $97.0 \pm 7.0$ & $73.9 \pm 3.6$ \\
\hline $\mathrm{Ca}^{2+}$ & $101.1 \pm 1.3$ & $106.2 \pm 5.4$ & $98.6 \pm 3.5$ & $101.4 \pm 3.4$ \\
\hline EDTA & $96.3 \pm 3.6$ & $96.7 \pm 1.0$ & $99.1 \pm 4.0$ & $97.9 \pm 2.6$ \\
\hline PMSF & $96.4 \pm 3.5$ & $89.8 \pm 5.0$ & $96.6 \pm 4.7$ & $54.8 \pm 3.6$ \\
\hline
\end{tabular}

Data are given as mean values \pm SD. Activity was measured after adding 1 or $5 \mathrm{mM}$ of various reagents into the reaction mixture. The activity without any additives was defined as $100 \%$
Additionally, another noteworthy property of EstS was its strong tolerance to $\mathrm{NaCl}$. EstS was active from 0 to $4 \mathrm{M} \mathrm{NaCl}$ and retained nearly $94 \%$ activity even at a salt concentration of $4 \mathrm{M} \mathrm{NaCl}$ (Fig. 5a). Unlike most halophlic enzymes which are inactive or unstable under low salt concentrations, EstS was active even without $\mathrm{NaCl}[27,28]$. This unique characteristic indicated EstS was halo-tolerant rather than halophilic. Furthermore, the presence of $\mathrm{NaCl}$ was unable to improve the activity of EstS as compared with other halo-tolerant and/or halophilic lipolytic enzymes, such as: the esterase EstPc from Psychrobacter cryohalolentis K5, which showed $179 \%$ activity at $1.75 \mathrm{M} \mathrm{NaCl}$ [29]; and esterase PE10 from Pelagibacterium halotolerans B2, which exhibited the maximum activity in the presence of $3 \mathrm{M} \mathrm{NaCl}$ [30]. Generally, halophilic proteins have a large number of acidic amino acids on the surface, whose negative charge acts to form protective hydrated ion network that keeps the protein stable in high salt concentrations [31, 32]. In the present study, EstS has a higher percentage of acidic amino acid (Asp + Glu: $12.25 \%$ ) than the basic amino acid (Arg + Lys: $8.61 \%$ ). EstS showed high negative charges on the surface, which is consistent with the distribution of the electrostatic potential of its model (Fig. 7), which clearly indicated that the halo-tolerance of EstS was depends upon structure and amino acid composition. The overall results from this study, suggests that EstS is a novel 
Table 2 Effect of organic solvents on the activity of Est WT and 1-D5

\begin{tabular}{|c|c|c|c|c|c|c|}
\hline \multirow{3}{*}{$\begin{array}{l}\text { Organic } \\
\text { solvent }\end{array}$} & \multicolumn{6}{|c|}{ Relative activity (\%) } \\
\hline & \multicolumn{3}{|l|}{ EstS } & \multicolumn{3}{|l|}{ 1-D5 } \\
\hline & $10 \%(v / v)$ & $20 \%(v / v)$ & $30 \%(v / v)$ & $10 \%(v / v)$ & $20 \%(v / v)$ & $30 \%(v / v)$ \\
\hline Control & $12.2 \pm 0.5 \mathrm{U} / \mathrm{ml}$ & $10.9 \pm 0.2 \mathrm{U} / \mathrm{ml}$ & $11.2 \pm 0.3 \mathrm{U} / \mathrm{ml}$ & $8.2 \pm 1 \mathrm{U} / \mathrm{ml}$ & $8.2 \pm 1 \mathrm{U} / \mathrm{ml}$ & $8.2 \pm 1 \mathrm{U} / \mathrm{ml}$ \\
\hline Isopropanol & $100.6 \pm 4.1$ & $12.0 \pm 2.3$ & $6.1 \pm 5.7$ & $66.8 \pm 1.7$ & $29.1 \pm 6.7$ & $14.6 \pm 1.6$ \\
\hline Acetone & $99.6 \pm 1.2$ & $103.9 \pm 4.0$ & $108.6 \pm 2.4$ & $46.2 \pm 6.1$ & $19.2 \pm 2.1$ & $11.6 \pm 0.2$ \\
\hline Methanol & $112.6 \pm 4.6$ & $46.5 \pm 4.9$ & $3.9 \pm 0.3$ & $79.6 \pm 5.2$ & $57.9 \pm 4.5$ & $33.0 \pm 4.0$ \\
\hline DMSO & $102.5 \pm 5.8$ & $119.8 \pm 3.7$ & $108.9 \pm 0.3$ & $90.2 \pm 5.4$ & $76.9 \pm 7.0$ & $40.5 \pm 4.5$ \\
\hline Ethanol & $121.4 \pm 3.5$ & $113.7 \pm 1.9$ & $110.5 \pm 2.5$ & $77 \pm 9.7$ & $44.6 \pm 3.9$ & $14.3 \pm 2.2$ \\
\hline N-butyl alcohol & ND & ND & ND & ND & ND & ND \\
\hline Ethylene glycol & $87.8 \pm 2.2$ & $83.7 \pm 4.3$ & $36.4 \pm 5.6$ & $90.9 \pm 5.5$ & $93.9 \pm 5.9$ & $90 \pm 5.2$ \\
\hline Acetonitrile & ND & ND & ND & ND & ND & ND \\
\hline
\end{tabular}

Data are given as mean values \pm SD. The activity without any additives was defined as $100 \%$. ND means not detected

cold active and halo-tolerant esterase and it may prove useful for immense biotechnological applications.

The major factors responsible for thermostability of proteins includes ionic interactions, hydrogen bonds, hydrophobic interactions and disulfide bonds [33]. In this work, a mutant 1-D5 was more thermo-stable than WT and showed three amino acid changes (A43V, R116W, D147N; Fig. 6). It was predicted that $\mathrm{Ala}^{43}$ of EstS is located in the loop near first $\beta$ sheet $(\beta 1)$ of enzyme and does not directly with the active center. The $\mathrm{Arg}^{116}$ of EstS, which replaced by Trp in 1-D5, is located in the loop between fourth $\beta$ sheet ( $\beta 4$ ) and second $\alpha$ helix $(\alpha 2)$ and the $\mathrm{Asp}^{147}$ of EstS is located in the loop near fifth $\beta$ sheet ( $\beta 5$ ) and the catalytic residue $\operatorname{Ser}^{157}$ is on the other side of $\beta 5$. Both position 116 and 147 are on the protein surface. The mutation R116W changed the polar amino acid residue to hydrophobic residues while the mutations $\mathrm{A} 43 \mathrm{~V}$ and $\mathrm{D} 147 \mathrm{~N}$ tend to increase the hydrophobicity of EstS [34]. This increase in the hydrophobicity lead to higher thermo-stability of 1-D5 than WT.

CD results demonstrated that the mutation of EstS did not affect the secondary structure of enzyme but improve the activity and stability.

\section{Conclusion}

A novel cold-active and salt-tolerant esterase was purified and characterized from marine bacterium Serratia sp. EstS showed remarkable catalytic activity at low temperature, extreme salt tolerance and good $\mathrm{pH}$ stability. All the characteristics collectively make it a potential candidate for industrial applications. Furthermore, a more thermo-stable esterase was obtained by errorprone PCR, and the experimental results may provide useful information for further study.

\section{Methods}

\section{Strains, vectors and reagents}

E. coli DH5 $\alpha$ (TaKaRa, Japan) and BL21 (DE3) (Novagen, USA) were used as cloning and expression hosts, respectively. The vector pGEX-6P-1 (GE Healthcare, USA) was used for gene cloning and protein expression. Serratia sp. and E. coli were grown in LB medium (tryptone $1 \%$, yeast extract $0.5 \%$ and $\mathrm{NaCl} 1 \% \mathrm{w} / \mathrm{v}$ ) at 28 and $37{ }^{\circ} \mathrm{C}$, respectively. $p$-nitrophenyl esters: $p$-NP acetate (C2), $p$-NP butyrate (C4), $p$-NP hexanoate (C6), $p$-NP caprylate $(\mathrm{C} 8), p$-NP laurate $(\mathrm{C} 12)$ and $p$-NP palmitate (C16) were all purchased from Sigma (St. Louis, MO, USA).

Table 3 Effect of detergents on the activity of WT and 1D-5 esterase

\begin{tabular}{|c|c|c|c|c|c|c|}
\hline \multirow[t]{3}{*}{ Detergents } & \multicolumn{6}{|c|}{ Relative activity (\%) } \\
\hline & \multicolumn{3}{|l|}{ EstS } & \multicolumn{3}{|l|}{$1-D 5$} \\
\hline & $0.5 \%$ & $1 \%$ & $5 \%$ & $0.5 \%$ & $1 \%$ & $5 \%$ \\
\hline Control & $8.8 \pm 0.1 \mathrm{U} / \mathrm{ml}$ & $11.0 \pm 0.2 \mathrm{U} / \mathrm{ml}$ & $10.9 \pm 0.3 \mathrm{U} / \mathrm{ml}$ & $8.4 \pm 0.8 \mathrm{U} / \mathrm{ml}$ & $8.4 \pm 0.8 \mathrm{U} / \mathrm{ml}$ & $8.4 \pm 0.8 \mathrm{U} / \mathrm{ml}$ \\
\hline TritonX-100 & $91.4 \pm 1.0$ & $96.3 \pm 2.5$ & $90.8 \pm 4.5$ & $84.3 \pm 5.7$ & $72.0 \pm 6.0$ & $39.1 \pm 0.6$ \\
\hline Tween-20 & $99.3 \pm 1.7$ & $97.7 \pm 1.7$ & $96.3 \pm 3.8$ & $86.5 \pm 5.3$ & $55.4 \pm 3.2$ & $45.8 \pm 1.3$ \\
\hline Tween-80 & $96.3 \pm 2.2$ & $98.4 \pm 0.2$ & $96.1 \pm 5.5$ & $90.9 \pm 4.4$ & $88.8 \pm 3.4$ & $83.4 \pm 3.6$ \\
\hline CHAPS & $110.1 \pm 2.9$ & $103.8 \pm 5.0$ & $3.1 \pm 6.4$ & $76.2 \pm 5.8$ & $46.6 \pm 5.2$ & $26.9 \pm 1.3$ \\
\hline SDS & ND & ND & ND & ND & ND & ND \\
\hline
\end{tabular}

Data are given as mean values \pm SD. The activity without any additives was defined as $100 \%$. ND means not detected 


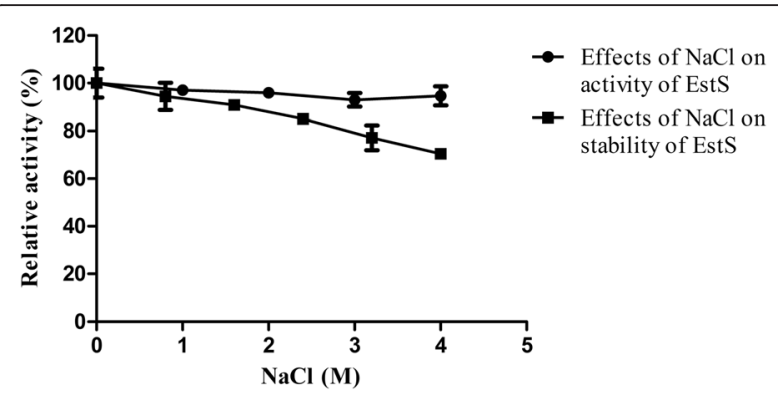

Fig. 5 Effects of $\mathrm{NaCl}$ on activity and stability of EstS. The enzyme activity (•) was assayed in $50 \mathrm{mM}$ Tris- $\mathrm{HCl}$ buffer ( $\mathrm{pH}$ 8.5) containing 0-4 $\mathrm{M} \mathrm{NaCl}$ and the residual activity ( $\mathbf{\square})$ of EstS was measured after incubating with $0-4 \mathrm{M} \mathrm{NaCl}(\mathrm{pH} 8.5)$ at $4{ }^{\circ} \mathrm{C}$ for $24 \mathrm{~h}$

\section{Gene cloning}

The cloning of estS gene of Serratia sp. was performed by PCR amplification with estS-F and estS-R primers. The forward primer estS-F 5-CCGGAATTCATGCCGC TTGATCCTCA-3 (with EcoRI restriction site underlined) and the reverse primer estS-R 5-CCGCTCGAGTCAGC CAACCTTGTCGA-3 (with XhoI restriction site underlined) were designed based on the sequence of the esterase gene GenBank: AGQ31273.1] of Serratia liquefaciens ATCC 27592. The whole genome of S. liquefaciens ATCC 27592 [GenBank: CP006252.1] was sequenced and published in GenBank by Nicholson et al [35]. The genomic DNA of Serratia sp. was used as template, PCR was performed with an initial denaturation at $94{ }^{\circ} \mathrm{C}$ for $3 \mathrm{~min}$; followed by 30 cycles of denaturation at $94{ }^{\circ} \mathrm{C}$ for $0.5 \mathrm{~min}$, annealing at $60{ }^{\circ} \mathrm{C}$ for $0.5 \mathrm{~min}$, and extension at $72{ }^{\circ} \mathrm{C}$ for $1 \mathrm{~min}$; and a final extension at $72{ }^{\circ} \mathrm{C}$ for $10 \mathrm{~min}$. The resulting product was digested by EcoRI and XhoI, ligated into the expression vector pGEX-6P-1 with the same digestion, and then transformed into competent $E$. coli DH5 $\alpha$ cells.

\section{Sequence analysis}

GenScript (Nanjing, China) was used to make sure that the gene was correctly inserted sequenced the recombinant plasmid pGEX-6p-estS. The deduced amino acid sequence of $e s t S$ was analyzed by blastp program and the SignalP 4.1 Server (http://www.cbs.dtu.dk/services/SignalP/) predicted the signal peptide. Moreover, the multiple sequence alignment was carried out using Clustal X 2.0.

Table 4 The kinetic parameters of the wild-type EstS and its mutant

\begin{tabular}{lllc}
\hline Enzyme & $K_{\mathrm{m}}(\mu \mathrm{M})$ & $K_{\text {cat }}\left(\mathrm{s}^{-1}\right)$ & $K_{\text {cat }} / K_{\mathrm{m}}\left(\mathrm{s}^{-1} \cdot \mu \mathrm{M}^{-1}\right)$ \\
\hline WT & $74.02 \pm 1.9$ & $2.339 \times 10^{3} \pm 4.6$ & $31.60 \pm 3.1$ \\
1-D5 & $87.59 \pm 2.4$ & $2.501 \times 10^{3} \pm 6.5$ & $28.55 \pm 3.7$ \\
\hline
\end{tabular}

Data are given as mean values \pm SD. All the assays were performed at the optimum $\mathrm{pH}$ and temperature

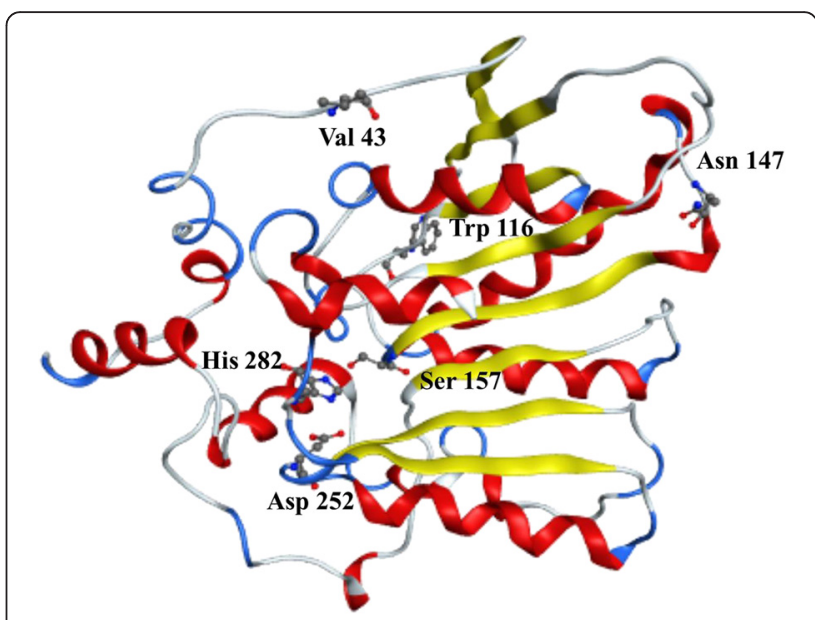

Fig. 6 Three-dimensional model of 1-D5. The catalytic sites and substitution sites were displayed with stick-ball model

\section{Construction of error-prone library}

The random mutant library was constructed by errorprone PCR reaction [36]. The $50 \mu \mathrm{l}$ reaction mixture contained $50 \mathrm{ng}$ of template plamid pGEX-6p-estS, $0.2 \mu \mathrm{M}$ forward primer estS-F and reverse primer estS-R, $0.2 \mathrm{mM}$ dATP, $0.2 \mathrm{mM}$ dGTP, $0.4 \mathrm{mM}$ dCTP, $0.4 \mathrm{mM}$ dTTP, $5 \mathrm{mM} \mathrm{Mg}^{2+}, 0.3 \mathrm{mM} \mathrm{Mn}^{2+}$ and $2.5 \mathrm{U}$ of Taq polymerase. The PCR reaction was carried out under similar condition as the gene cloning of estS. The amplified product was digested by EcoRI and XhoI and ligated in the pGEX-6p-1 vector. The recombinant plasmids were transformed into $E$. coli $\mathrm{DH} 5 \alpha$ cell. The resultant clones were spread onto LB agar plate and incubated at $37^{\circ} \mathrm{C}$.

\section{Screening of mutants}

The mutants were grown for $12 \mathrm{~h}$ on LB agar plate and colonies were picked with sterile toothpicks and grown in 96-deep well plates containing $600 \mu \mathrm{l} \mathrm{LB}$ medium supplimented with ampicillin $(100 \mu \mathrm{g} / \mathrm{ml})$ along with WT clone (cell harboring pGEX-6p-estS). Each well was supplemented with $150 \mu$ l flesh LB-Amp medium containing $1 \mathrm{mM}$ IPTG and T7 phage. The cells were induced and lysed at $28{ }^{\circ} \mathrm{C}$ for $6 \mathrm{~h}$ followed by incubation at $50{ }^{\circ} \mathrm{C}$ for $40 \mathrm{~min}$. Subsequently, the plates were cooled at $4{ }^{\circ} \mathrm{C}$ for $10 \mathrm{~min}$, and $20 \mu \mathrm{l}$ of lysate was transferred to 96-well plates to assay residual enzyme activity at room temperature. The mutants that showed higher residual enzyme activity were selected for further experiments. Finally, the DNA of mutants was isolated, sequenced and compared with the WT to locate the changed amino acid.

\section{Expression and purification of WT and mutant}

The recombinant plasmid pGEX-6p-esterase (WT and mutant) were transformed into E. coli BL21 (DE3) and 

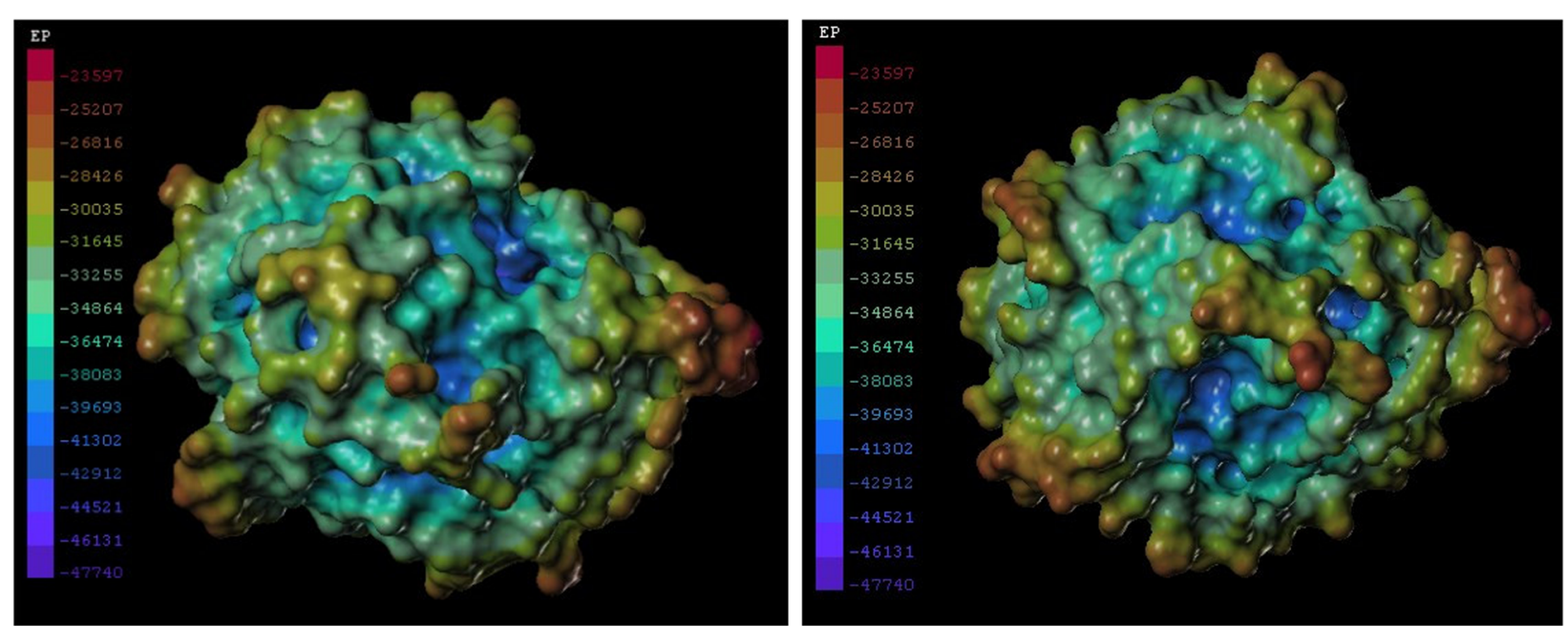

Fig. 7 The surface electrostatic potential of EstS. The most negative and most positive electrostatic potentials are indicated by purple and red, respectively. The right image is the $180^{\circ}$ rotated view of the left one

the cells were grown for $12 \mathrm{~h}$ at $37{ }^{\circ} \mathrm{C}$ in $\mathrm{LB}$ medium containing ampicillin $(100 \mu \mathrm{g} / \mathrm{ml})$. When the optical density of the culture reached 0.6 at $\mathrm{OD}_{600}$, the cells were induced by adding isopropyl- $\beta$-D-thiogalactopyranoside (IPTG; $0.2 \mathrm{mM}$ ). After induction for $16 \mathrm{~h}$ at $15{ }^{\circ} \mathrm{C}$, the cells were harvested by centrifugation $(8000 \mathrm{rpm})$ at $4{ }^{\circ} \mathrm{C}$ for $10 \mathrm{~min}$, followed by washing, resuspension in PBS buffer $\left(0.8 \% \mathrm{NaCl}, 0.02 \% \mathrm{KCl}, 0.142 \% \mathrm{Na}_{2} \mathrm{HPO}_{4}\right.$, $\left.0.027 \% \mathrm{KH}_{2} \mathrm{PO}_{4} ; \mathrm{pH} 7.4\right)$. The disruption of cells was carried out by French pressure cell. The cell lysate was collected by centrifugation $(12,000 \mathrm{rpm})$ at $4{ }^{\circ} \mathrm{C}$ for $40 \mathrm{~min}$. The supernatant was purified by Glutathione-Sepharose column (GE Healthcare, USA) as described previously [37]. Finally, the target protein, wild-type and mutant esterase was released from the GST-tag attached to the column by the 3C

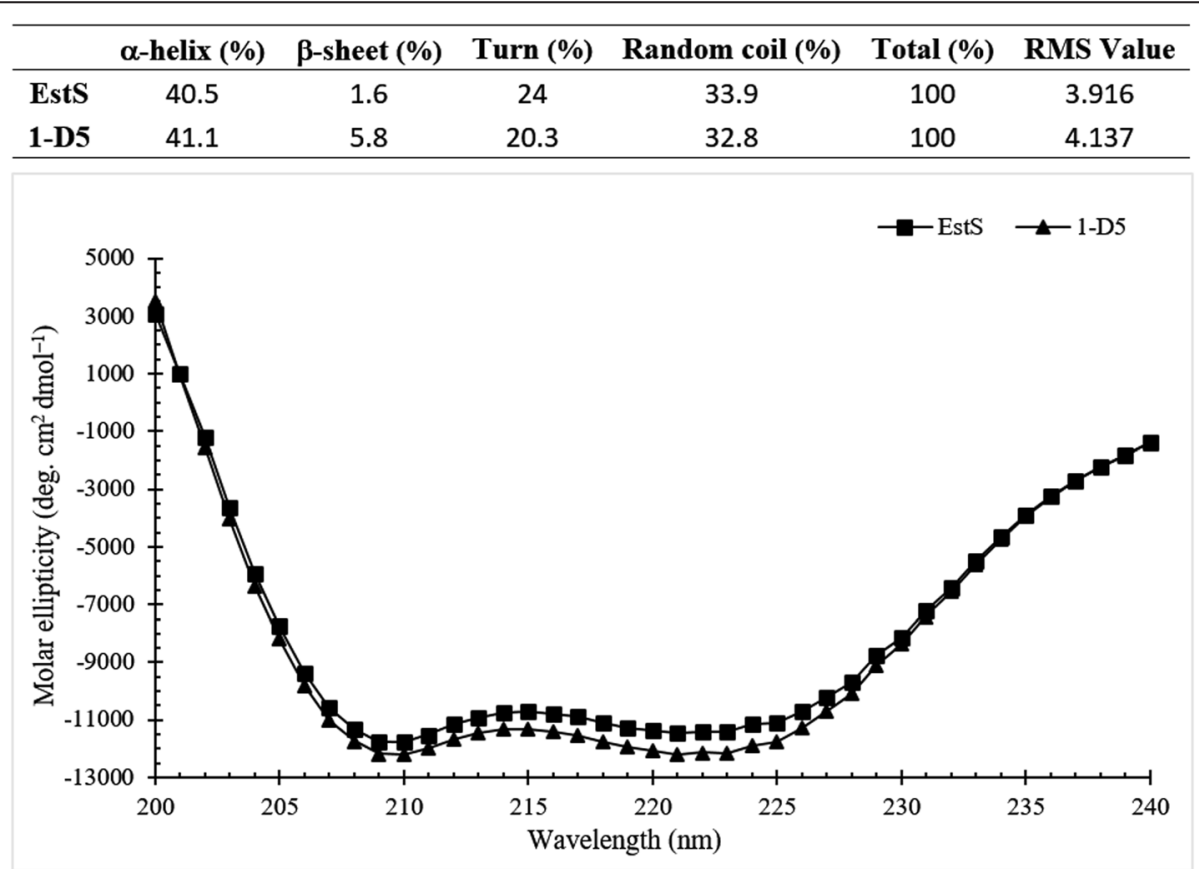

Fig. 8 CD spectra of the EstS and 1-D5 in the far-UV spectral region (195-250 nm). CD spectra of Est WT and 1-D5 was more or less similar and an increase in the percentage of $\beta$-sheets was reported by $C D$ analysis 
protease solution (10 U/ $\mu$ l, PreScission, Pharmacia). The purified protein was analyzed by SDS-PAGE in $12 \%$ polyacrylamide gels. Protein concentration was determined by the Bradford method [38], using bovine serum albumin as standard.

\section{Enzyme assay}

The esterase activity was determined by measuring the amount of $p$-nitrophenol released in the standard reaction mixture with the OD values at $405 \mathrm{~nm}$ monitored by Thermo Scientific Multiscan Spectrum. The standard reaction mixture contained $10 \mu \mathrm{l}$ of enzyme, $2 \mu \mathrm{l}$ of $p$-NP ester $(20 \mathrm{mM})$ in ethanol and $188 \mu \mathrm{l}$ of Tris- $\mathrm{HCl}$ buffer ( $50 \mathrm{mM}, \mathrm{pH}$ 8.5). The reaction mixture in which enzyme is replaced with PBS was considered as control. All experiments were carried out in triplicate and the data obtained were analyzed using GraphPad Prism 5.0 and Excel 2010 software. The calculated values were expressed as mean \pm standard deviation (SD) with the statistical significance at $p<0.05$ and standard deviation was calculated by standard deviation function (STDEV) in Excel. One unit of enzyme activity was defined as the amount of enzyme needed to release $1 \mu \mathrm{mol}$ of $p$-nitrophenol per minute under the above reaction conditions. The experiments were performed in triplicate and average values were calculated with standard deviations.

\section{Substrate specificity}

The substrate specificity was investigated with $p$-NP esters of different chain lengths (acetate, C2; butyrate, $\mathrm{C} 4$; hexanoate, C6; caprylate, C8; laurate, C12; palmitate, C16). The hydrolytic reactions were performed in triplicate under standard assay conditions with each substrate.

\section{Biochemical characterization of esterase}

The optimum temperature of esterase was determined by incubating the reaction mixtures at a temperature range of 0 to $80{ }^{\circ} \mathrm{C}$ with $p$-NP acetate $(\mathrm{C} 2)$ as substrate. The thermal stability was determined by measuring the residual enzyme activity after exposing the enzyme solution separately to three different temperatures $(45,50$ and $55{ }^{\circ} \mathrm{C}$ ) for varying time intervals. The $\mathrm{pH}$ optimum was investigated in following buffers: phosphate-citrate buffer (pH 5.0-7.0) and Tris- $\mathrm{HCl}$ buffer ( $\mathrm{pH} 7.0-10.0)$. The $\mathrm{pH}$ stability was evaluated by incubating the enzyme in various $\mathrm{pH}$ buffer solutions for $24 \mathrm{~h}$ at $4{ }^{\circ} \mathrm{C}$. The remaining enzyme activity was assayed under the standard conditions.

The effects of metal ions $\left(\mathrm{Mg}^{2+} \mathrm{Sr}^{2+}, \mathrm{Ba}^{2+}, \mathrm{Zn}^{2+}, \mathrm{Mn}^{2+}\right.$, $\mathrm{Cu}^{2+}, \mathrm{Ca}^{2+}$ ) and reagents (EDTA, PMSF) on esterase activity were examined at a final concentration of 1 and $5 \mathrm{mM}$ in Tris- $\mathrm{HCl}$ buffer $(\mathrm{pH}$ 8.5). The effects of organic solvents and detergents were evaluated by diluting the enzyme solution in different final concentrations (10-30 \%) of organic solvents and detergents, including iso-propanol, acetone, methanol, DMSO, ethanol, $n$-butyl alcohol, ethylene glycol, acetonitrile, TritonX-100, Tween-20, Tween-80, CHAPS and SDS. Samples containing only the same amount of reagent were used as control. The enzyme activity without additives in the reaction mixture was considered as $100 \%$. The effect of $\mathrm{NaCl}$ on enzyme activity was determined with $0-4 \mathrm{M} \mathrm{NaCl}$ dissolved in Tris- $\mathrm{HCl}$ buffer ( $50 \mathrm{mM}, \mathrm{pH}$ 8.5). The effect of $\mathrm{NaCl}$ on enzyme stability was evaluated by treating enzyme solutions in the above-mentioned $\mathrm{NaCl}$ solutions at $4{ }^{\circ} \mathrm{C}$ for $24 \mathrm{~h}$.

\section{Kinetic measurements}

The kinetic parameters $\left(k_{c a t}, V_{\max }\right.$, and $\left.k_{\mathrm{m}}\right)$ were determined by measuring the reaction rate of WT and mutant in different substrate ( $p$-NP acetate) concentration $(0.01-0.3 \mathrm{mM})$ at $10{ }^{\circ} \mathrm{C}$ for $10 \mathrm{~min}$. The kinetic parameters $V_{\max }$ and $k_{\mathrm{m}}$ were determined by LineweaverBurk plot using Michaelis-Menten equation with Graphpad Prism software (Graphpad, San Diego, CA). The $k_{\text {cat }}$ parameter was calculated using the equation $k_{\text {cat }}=V_{\text {max }} /[\mathrm{E}]$.

\section{Homology modeling}

To gain insights into the structure of WT and mutant esterase, a homology model was generated automatically with Swiss-model server (http://swissmodel.expasy.org/; [39]. Based on the model, the electrostatic potential on the surface of esterase was visualized by the software SYBYL and the amino acid changes were analyzed by MOE 2009.

\section{Circular dichroism analysis}

Secondary structure of Est WT and 1-D5 was predicted by using the program PSIPRED [40]. Circular dichroism (CD) spectra of Est WT and 1-D5 were recorded with a Jasco-810 CD spectrometer (Jasco Corp., Japan). The data were collected at room temperature from 195 to $250 \mathrm{~nm}$ using $2 \mathrm{~mm}$ quartz cuvette $(600 \mu \mathrm{l})$. The conversion to the Mol CD $(\Delta \varepsilon)$ in each spectrum was performed with the Jasco Standard Analysis software. Estimation of the secondary structure content from far-UV circular dichroism (CD) spectra was performed by using the CDPro software package (available at http://lamar.colostate.edu/ sreeram/CDPro/ main.html), including three executable programs (SELCON3, CDSSTR, and CONTIN/LL) [41]. In this study, the percentages of $\alpha$-helix and $\beta$-sheet for each protein sample were averaged by the calculations of results from the CDPro software package. The circular dichroism data were expressed in terms of the 
mean residue ellipticity $\left(\theta_{\text {mrw }}\right)$,which calculated with using the equation [42]:

$$
\theta_{\mathrm{mrw}}=\frac{M_{w} \cdot \theta_{\mathrm{obs}} \cdot 100}{\mathrm{~N} \cdot d \cdot c}
$$

where $\theta_{\text {obs }}$ is the observed ellipticity in degrees, Mw is the protein molecular weight of WT and 1-D5, and $\mathrm{N}$ is the number of residues, $d$ is the path length of quartz cuvette $(0.2 \mathrm{~cm}), c$ is the protein concentration $(\mathrm{mg} / \mathrm{ml})$, and the constant number 100 stems from the conversion of the molecular weight to $\mathrm{mg} / \mathrm{dmol}$.

\section{Availability of supporting data}

The additional data supporting the results of this article is available online in the National Center for Biotechnology Information [NCBI] repository, [GenBank accession number:KU362566].

\section{Competing interests}

The authors declare that they have no competing interests.

\section{Authors' contributions}

$\mathrm{HJ}$ and SWZ designed and performed the experiments and drafted this manuscript. SWZ performed purification, characterization and Circular dichroism analysis. HFG contributed to characterization, expression experiments and revised the manuscript. $\mathrm{NH}$ conceived, designed and supervised the experiments, is a corresponding author. All authors have read and approved the manuscript.

\section{Acknowledgements}

This work was supported by grants from National Science Foundation of China (No. 31270162) and the Priority Academic Program Development of Jiangsu Higher Education Institutions.

\section{Author details}

${ }^{1}$ College of Biotechnology and Pharmaceutical Engineering, Nanjing Tech University, Nanjing 211800, P. R. China. ${ }^{2}$ State Key Laboratory of Agricultural Microbiology, College of Life Science and Technology, Huazhong Agricultural University, Wuhan 430070, P. R. China.

Received: 26 July 2015 Accepted: 13 January 2016

Published online: 22 January 2016

\section{References}

1. Arpigny J, Jaeger K. Bacterial lipolytic enzymes: classification and properties. Biochem J. 1999;343:177-83.

2. Li XL, Zhang WH, Wang YD, Dai YJ, Zhang HT, Wang Y, et al. A high-detergent-performance, cold-adapted lipase from Pseudomonas stutzeri PS59 suitable for detergent formulation. J Mol Catalysis B Enzymatic. 2014;102:16-24.

3. Tutino ML, Parrilli E, De Santi C, Giuliani M, Marino G, de Pascale D. Cold-adapted esterases and lipases: a biodiversity still under-exploited. Curr Chem Biol. 2010;4(1):74-83.

4. Suzuki T, Nakayama T, Choo DW, Hirano Y, Kurihara T, Nishino T, et al. Cloning, heterologous expression, renaturation, and characterization of a cold-adapted esterase with unique primary structure from a psychrotroph Pseudomonas sp. strain B11-1. Protein Expr Purif. 2003;30(2):171-8.

5. Kulakova L, Galkin A, Nakayama T, Nishino T, Esaki N. Cold-active esterase from Psychrobacter sp. Ant300: gene cloning, characterization, and the effects of Gly $\rightarrow$ Pro substitution near the active site on its catalytic activity and stability. Biochim Biophys Acta Protein Proteomics. 2004;1696(1):59-65.

6. Ryu H, Kim H, Choi W, Kim M, Park S, Han N, et al. New cold-adapted lipase from Photobacterium lipolyticum sp. nov. that is closely related to filamentous fungal lipases. Appl Microbiol Biotechnol. 2006;70(3):321-6.

7. Bornscheuer UT. Microbial carboxyl esterases: classification, properties and application in biocatalysis. FEMS Microbiol Rev. 2002;26(1):73-81.
8. Romano D, Bonomi F, de Mattos MC, Fonseca TD, de Oliveira MDF, Molinari F. Esterases as stereoselective biocatalysts. Biotechnol Adv. 2015;33(5):547-65.

9. Khurana J, Singh R, Kaur J. Engineering of Bacillus lipase by directed evolution for enhanced thermal stability: effect of isoleucine to threonine mutation at protein surface. Mol Biol Rep. 2011;38(5):2919-26.

10. Cao L, Chen R, Xie W, Liu Y. Enhancing the thermostability of feruloyl esterase EstF27 by directed evolution and the underlying structural basis. J Agric Food Chem. 2015.

11. Khan MIH, Ito K, Kim H, Ashida H, Ishikawa T, Shibata H, et al. Molecular properties and enhancement of thermostability by random mutagenesis of glutamate dehydrogenase from Bacillus subtilis. Biosci Biotechnol Biochem. 2005;69(10):1861-70

12. Wang M, Si T, Zhao H. Biocatalyst development by directed evolution. Bioresour Technol. 2012:115:117-25.

13. Kim J, Kim S, Yoon S, Hong E, Ryu Y. Improved enantioselectivity of thermostable esterase from Archaeoglobus fulgidus toward (S)-ketoprofen ethyl ester by directed evolution and characterization of mutant esterases. Appl Microbiol Biotechnol. 2015;1-9.

14. Chronopoulou EG, Labrou NE. Site saturation mutagenesis: A powerful tool for structure based design of combinatorial mutation libraries. Curr Protoc Protein Sci. 2011; 26.26. 21-26.26. 10.

15. Packer MS, Liu DR. Methods for the directed evolution of proteins. Nat Rev Genet. 2015.

16. Gaber Y, Ismail M, Bisagni S, Takwa M, Hatti-Kaul R. Rational mutagenesis of pig liver esterase (PLE-1) to resolve racemic clopidogrel. J Mol Catal B: Enzym. 2015;122:156-62.

17. Wu G, Zhang X, Wei L, Wu G, Kumar A, Mao T, et al. A cold-adapted, solvent and salt tolerant esterase from marine bacterium Psychrobacter pacificensis. Int J Biol Macromol. 2015;81:180-7.

18. Fadhil L, Kadim A, Mahdi A. Production of chitinase by Serratia marcescens from soil and its antifungal activity. J Nat Sci Res. 2014;4(8):80-6.

19. Zhang S, Wu G, Liu Z, Shao Z, Liu Z. Characterization of EstB, a novel coldactive and organic solvent-tolerant esterase from marine microorganism Alcanivorax dieselolei B-5 (T). Extremophiles. 2014;18(2):251-9.

20. Wu G, Wu G, Zhan T, Shao Z, Liu Z. Characterization of a cold-adapted and salt-tolerant esterase from a psychrotrophic bacterium Psychrobacter pacificensis. Extremophiles. 2013;17(5):809-19.

21. Fu J, Leiros H-KS, de Pascale D, Johnson KA, Blencke H-M, Landfald B. Functional and structural studies of a novel cold-adapted esterase from an Arctic intertidal metagenomic library. Appl Microbiol Biotechnol. 2013;97(9):3965-78.

22. Hårdeman F, Sjöling S. Metagenomic approach for the isolation of a novel low temperature active lipase from uncultured bacteria of marine sediment. FEMS Microbiol Ecol. 2007;59(2):524-34.

23. Siddiqui KS, Cavicchioli R. Cold-adapted enzymes. Annu Rev Biochem. 2006;75:403-33.

24. Zhou X-X, Wang Y-B, Pan Y-J, Li W-F. Differences in amino acids composition and coupling patterns between mesophilic and thermophilic proteins. Amino Acids. 2008;34(1):25-33.

25. De Simone G, Galdiero S, Manco G, Lang D, Rossi M, Pedone C. A snapshot of a transition state analogue of a novel thermophilic esterase belonging to the subfamily of mammalian hormone-sensitive lipase. J Mol Biol. 2000;303(5):761-71.

26. Hotta Y, Ezaki S, Atomi H, Imanaka T. Extremely stable and versatile carboxylesterase from a hyperthermophilic archaeon. Appl Environ Microbiol. 2002:68(8):3925-31.

27. Madern D, Ebel C, Zaccai G. Halophilic adaptation of enzymes. Extremophiles. 2000;4(2):91-8.

28. Ventosa A, Sánchez-Porro C, Martín S, Mellado E. Halophilic archaea and bacteria as a source of extracellular hydrolytic enzymes. In: GundeCimerman N, Oren A, Plemenitaš A, editors. Adaptation to life at high salt concentrations in Archaea, Bacteria, and Eukarya. Netherlands: Springer; 2005. p. 337-54

29. Novototskaya-Vlasova K, Petrovskaya L, Yakimov S, Gilichinsky D. Cloning, purification, and characterization of a cold adapted esterase produced by Psychrobacter cryohalolentis K5T from Siberian cryopeg. FEMS Microbiol Ecol. 2012;82(2):367-75.

30. Jiang $X$, Huo Y, Cheng H, Zhang X, Zhu X, Wu M. Cloning, expression and characterization of a halotolerant esterase from a marine bacterium Pelagibacterium halotolerans B2T. Extremophiles. 2012;16(3):427-35. 
31. Fukuchi S, Yoshimune K, Wakayama M, Moriguchi M, Nishikawa K. Unique amino acid composition of proteins in halophilic bacteria. J Mol Biol. 2003;327(2):347-57.

32. Müller-Santos M, de Souza EM, Pedrosa FO, Mitchell DA, Longhi S, Carrière $F$, et al. First evidence for the salt-dependent folding and activity of an esterase from the halophilic archaea Haloarcula marismortui. Biochim Biophys Acta (BBA) J Mol Cell Biol Lipids. 2009;1791(8):719-29.

33. Beeby M, O Connor BD, Ryttersgaard C, Boutz DR, Perry L, Yeates TO. The genomics of disulfide bonding and protein stabilization in thermophiles. PLoS Biol. 2005;3(9):1549.

34. Black SD, Mould DR. Development of hydrophobicity parameters to analyze proteins which bear post-or cotranslational modifications. Anal Biochem. 1991;193(1):72-82.

35. Nicholson WL, Leonard MT, Fajardo-Cavazos P, Panayotova N, Farmerie WG, Triplett EW, et al. Complete genome sequence of Serratia liquefaciens strain ATCC 27592. Genome Announcements. 2013;1 (4):e00548-13.

36. Cirino PC, Mayer KM, Umeno D. Generating mutant libraries using errorprone PCR. In: Arnold FH, Georgiou G, editors. Directed evolution library creation. Humana Press; 2003. p. 3-9.

37. Cao S, Liu Z, Guo A, Li Y, Zhang C, Gaobing W, et al. Efficient production and characterization of Bacillus anthracis lethal factor and a novel inactive mutant rLFm-Y236F. Protein Expr Purif. 2008:59(1):25-30.

38. Bradford MM. A rapid and sensitive method for the quantitation of microgram quantities of protein utilizing the principle of protein-dye binding. Anal Biochem. 1976;72(1):248-54.

39. Arnold K, Bordoli L, Kopp J, Schwede T. The SWISS-MODEL workspace: a web-based environment for protein structure homology modelling. Bioinformatics. 2006;22(2):195-201.

40. McGuffin LJ, Bryson K, Jones DT. The PSIPRED protein structure prediction server. Bioinformatics (Oxford, England). 2000;16(4):404-5.

41. Sreerama N, Woody RW. Estimation of protein secondary structure from circular dichroism spectra: comparison of CONTIN, SELCON, and CDSSTR methods with an expanded reference set. Anal Biochem. 2000;287(2):252-60

42. Chaloupková R, Sýkorová J, Prokop Z, Jesenská A, Monincová M, Pavlová M, et al. Modification of activity and specificity of haloalkane dehalogenase from Sphingomonas paucimobilis UT26 by engineering of its entrance tunnel. J Biol Chem. 2003;278(52):52622-8.

\section{Submit your next manuscript to BioMed Central and we will help you at every step:}

- We accept pre-submission inquiries

- Our selector tool helps you to find the most relevant journal

- We provide round the clock customer support

- Convenient online submission

- Thorough peer review

- Inclusion in PubMed and all major indexing services

- Maximum visibility for your research

Submit your manuscript at www.biomedcentral.com/submit

) Biomed Central 